\title{
The Effect of Glenohumeral Joint Injection Prior to Physical Therapy on Treatment Outcomes in Adhesive Capsulitis
}

\author{
(iD) Alper Mengi ${ }^{1}$ \\ ${ }^{1}$ M.D. Spec., Istanbul University, Cerrahpaşa Faculty of Medicine, Department of Algology, Istanbul, Turkey. \\ $\ddot{0 z}$
}

Adeziv Kapsülit Tedavisinde Fizik Tedavi Programı Öncesi Uygulanan Glenohumeral Eklem Enjeksiyonunun Tedavi Sonuçları Üzerine Etkisi

Amaç:Bu çalıșmanın amacı, omuzda adeziv kapsüliti (AK) olan hastalarda fizik tedavi ve egzersiz programı (FTEP) öncesinde uygulanan ultrason eșliğinde intraartiküler (IA) glenohumeral eklem enjeksiyonunun tedavi sonuçları üzerine katkı sağlayıp sağlamadığını değerlendirmektir. Gereç ve Yöntem: 1 Ekim 2019 - 1 Mart 2020 tarihleri arasında, üç hafta boyunca haftada beș seans aynı fizik tedavi modaliteleri (yüzeyel ısıtma (infrared), transkutanöz elektriksel sinir stimülasyonu ve terapötik ultrasondan oluşan) ve egzersiz tedavisi uygulanan AK tanılı 93 hastanın tıbbi kayıtları retrospektif olarak değerlendirildi. Dahil etme ve dıșlama kriterlerini karșılayan toplam 41 hasta enjeksiyon uygulaması açısından iki gruba ayrıldı. FTEP'den önce ultrason eșliğinde İA glenohumeral enjeksiyon uygulanan hastalar "enjeksiyon yapılan hastalar" $(n=19)$, diğer hastalar "enjeksiyon yapılmayan hastalar" ( $n=22)$ olarak kabul edildi. Hastaların bașlangıçta (0. gün) ve FTEP'nin sonunda (21. gün), etkilenen omuzdaki aktif ve pasif eklem hareket açıkığı (EHA), ağrı şiddeti, ağrı ve sakatlık dereceleri değerlendirildi.

Bulgular: AK tedavisinde kullanılan fizik tedavi modaliteleri ve egzersiz tedavisi, üç haftanın sonunda ağrı skorları, EHA ve özürlülük skorları üzerinde olumlu bir etkiye sahipti. Bu tedaviden önce ultrason eșliğinde uygulanan İA enjeksiyonun, gündüz ve gece ağrı șiddetleri üzerinde olumlu etkisinin olduğu, ancak ROM veya sakatlık üzerine ek katkı sağlamadı̆̆ı belirlendi.

Sonuç: FTEP'den önce ultrason eșliğinde uygulanan glenohumeral IA enjeksiyon tedavisi, ağrı semptomlarının baskın olduğu AK hastalarında faydalı olabilir.

Anahtar Kelimeler: Donuk Omuz, Omuz Ağrısı, Ultrasonografi, Kortikosteroid, Fizyoterapi

\section{Abstract}

The Effect of Glenohumeral Joint Injection Prior to Physical Therapy on Treatment Outcomes in Adhesive Capsulitis

Objective: The objective of this study was to evaluate whether ultrasound-guided intraarticular (IA) glenohumeral injection applied before physical therapy and exercise therapy program (PTETP) contributes to the treatment outcomes in patients with adhesive capsulitis of the shoulder (ACS).

Methods: The medical records of 93 patients diagnosed with ACS who underwent the same physical therapy modalities five sessions per week for three weeks (consisted of superficial heating (infrared), transcutaneous electrical nerve stimulation, and therapeutic ultrasound) and exercise therapy program between October 1, 2019-March 1, 2020 were retrospectively evaluated. A total of 41 patients who met inclusion and exclusion criteria were divided into two groups in terms of injection application. Patients who were applied ultrasound guided IA glenohumeral injections before PTETP were considered "injection patients" (n=19), while other patients were considered "non-injection patients" ( $n=22)$. The active and passive range of motion (ROM), severity of pain, and degrees of pain and disability of the affected shoulders were assessed at baseline (day 0) and end of PTETP (day 21).

Results: Physical therapy modalities and exercise therapy used in ACS treatment had a positive effect on pain scores, ROM, and disability scores at the end of three weeks. It was determined that ultrasound-guided IA injection prior to this treatment the positive effect on daytime and nighttime pain but did not provide additional benefit on ROM or disability.

Conclusion:Ultrasound-guided glenohumeral IA injection therapy before PTETP may be beneficial in ACS patients with predominant symptoms of pain.

Keywords: Frozen Shoulder, Shoulder Pain, Ultrasonography, Corticosteroid, Physiotherapy

Nasıl Atıf Yapmalı: Mengi A. The Effect of Glenohumeral Joint Injection Prior to Physical Therapy on Treatment Outcomes in Adhesive Capsulitis. MKÜ Tıp Dergisi. 2021;12(44):165-171. https://doi.org/10.17944/mkutfd.918699

Sorumlu Yazar/Corresponding Author: M.D. Spec. Alper Mengi

Geliș/Received: 17 Nisan 2021

Email: a_mengi22@hotmail.com

Kabul/Accepted: 14 Eylül 2021

ORCID iD: 0000-0003-0898-764X 


\section{INTRODUCTION}

Adhesive capsulitis of the shoulder (ACS) is a shoulder pathology in which active and passive range of motion (ROM) of the shoulder is restricted and accompanied by pain (1). It is encountered in little more than $2 \%$ of the general population (2). The purpose of ACS treatment is to increase the patient's shoulder movements by reducing the pain, and thus restoring shoulder function (1). The conservative approach establishes the basis of ACS treatment; approximately 90\% of patients are successfully treated with conservative methods (3). Oral non-steroidal anti-inflammatory drugs (NSAIDs), physical therapy modalities, therapeutic exercises, and procedures such as glenohumeral intraarticular (IA) injection and suprascapular nerve block are frequently used conservative methods of treatment (4-6).

Exercise therapy is a key component of ACS treatment. It has been reported that stretching exercises are especially effective and that an exercise program performed under supervision is more effective than other exercise programs $(6,7)$. Physical therapy modalities such as therapeutic heating and analgesic currents are often combined with exercise therapy to help the patient regain ROM and function in the affected shoulder $(4,5)$. The addition of heating modalities to exercise therapy has been shown to reduce pain, increase ROM, and improve daily activities in patients with ACS $(4,8)$. IA steroid injections take effect by reducing synovial inflammation in the treatment of ACS and may allow an earlier functional recovery (9). IA steroid injections of the shoulder are usually combined with physical therapy procedures and are applied as additional therapy (10). It has been reported that a combination of IA steroid therapy with other treatment modalities may provide a greater increase in shoulder ROM and function (11).

Although combinations of different types of physical therapy agents, exercises, and IA injections have been studied, we did not encounter any study in the literature in which superficial/deep heat and analgesic currents, which we frequently use in our daily practice, exercise, and IA injection therapy were used together. In this study, it was evaluated the shortterm effects of ultrasound-guided IA glenohumeral injection therapy, applied before physical therapy, which consisted of deep and superficial heating and analgesic currents and exercise therapy, on ROM, pain, and disability scores of patients. Thus, it was aimed to evaluate whether IA injection therapy applied before physical therapy and exercise therapy contributes to the treatment outcomes.

\section{MATERIAL AND METHODS}

Patients who underwent a physical therapy and rehabilitation program with the diagnosis of ACS between October 1, 2019 - March 1, 2020 at Çanakkale Mehmet Akif Ersoy State
Hospital's Physical Therapy and Rehabilitation outpatient clinic and met inclusion and exclusion criteria were included in the study.

\section{Patient Selection}

Inclusion criteria were as follows: age between 18-65 years, detecting more than $1 / 3$ limitation in two or more planes in active and passive movements of the painful shoulder, pain and limited movement in the shoulder for at least 12 weeks, and pain and limitation in only one shoulder. Exclusion criteria were as follows: history of trauma and/or surgery in the same shoulder region; pain and limited motion in the shoulder for longer than 9 months; local injection and/or physical therapy in the shoulder in the last 3 months; patients with history of infectious or chronic inflammatory disease, or malignancy; patients with uncontrolled coagulation disorder; uncontrolled diabetes mellitus; calcific tendinitis, glenohumeral osteoarthritis, or acromioclavicular joint osteoarthritis detected in x-ray; complex regional pain syndrome, entrapment neuropathy, or vascular disease of the extremity on the same side; history of cerebrovascular disease; pregnant or breastfeeding women.

\section{Study design}

The medical records of 93 patients diagnosed with ACS who underwent a physical therapy and rehabilitation program were retrospectively evaluated. Among the patients who were evaluated, patients who met the study's inclusion and exclusion criteria, and completed the physical therapy and rehabilitation program from start to finish were divided into two groups in terms of injection application. Patients who were applied ultrasound-guided IA glenohumeral injections before the physical therapy and rehabilitation program were considered "injection patients", while those who did not accept injections were considered "non-injection patients".

\section{Physiotherapy modalities and exercise therapy}

All patients underwent the same physical therapy modalities 5 sessions per week for 3 weeks: superficial heating (infrared), transcutaneous electrical nerve stimulation (TENS), and therapeutic ultrasound (TUS). Infrared application was applied to the patient in seated position with a device equipped with two Philips infrared lamps (each lamp 250-watt power) with approximately $50 \mathrm{~cm}$ distance between the patient and the lamp for 20 minutes. TENS (pulse duration of $100 \mu$ s, frequency of 100 Hertz, sensory-level amplitude) was applied for 25 minutes with a BTL-5820S Combi. During the application, four TENS electrodes with two outlets were placed crosswise around the shoulder surrounding the painful region. TUS was applied to the patient's shoulder joint and its immediate surroundings in seated position for 5 minutes in continuous mode with the BTL-5820S Combi (frequency of 1 $\mathrm{MHz}$, intensity of $1.5 \mathrm{~W} / \mathrm{cm}^{2}$, effective irradiation area of the 
transducer head $5 \mathrm{~cm}^{2}$ ). A pharmacological substance free gel was applied to the transducer head, which was moved slowly and circularly over the shoulder region.

All patients underwent an exercise program consisting of Codman exercises, finger ladder, and active-passive shoulder stretching exercises under the supervision of the same physiotherapist throughout the treatment. All exercises were performed at the threshold of shoulder pain and the patients were advised not to do exercises that would exceed the pain threshold. During the treatment, the patients were advised repeat the same exercise program twice daily at home (15 min each round).

\section{Injection application}

Injections were made with the posterior approach under ultrasound guidance 4 days before the start of the physical therapy and rehabilitation program. All injections were made by the researcher AM, a physiatrist with 6 years of experience in this field. A 22-gauge $88 \mathrm{~mm}$ needle was used in injections, which were performed with a 5-10 MHz superficial linear probe (Mindray, Shenzhen, China). With the patient in seated position, the arm was placed in a neutral position and the injection site was cleaned with povidone-iodine. The needle was advanced from lateral to medial until it reached the glenohumeral joint cavity between the posterior humeral head and the posterior glenoid labrum with the in-plane approach. The injections consisted of $1 \mathrm{ml}$ of combined betamethasone suspension ( $2 \mathrm{mg}$ betamethasone sodium phosphate and 5 $\mathrm{mg}$ betamethasone dipropionate), $5 \mathrm{ml}$ of $0.5 \%$ lidocaine hydrochloride, and $4 \mathrm{ml}$ of saline.

\section{Evaluation criteria}

The patients who were included in the study were evaluated in terms of gender, age, body mass index (BMI), duration of symptoms (months), dominant side, and symptomatic side. The active and passive ROM, severity of pain, and degrees of pain and disability of the affected shoulders were assessed at the start (baseline) and end (day 21) of the physical therapy and rehabilitation program.

A universal goniometer was used to evaluate shoulder ROM. Active and passive flexion, abduction, adduction, internal-external rotation ROMs were measured while the patients were laying in the supine position, while extension ROMs were measured while the patients were laying in the prone position, and all measurements were made by the same physiotherapist (12).

Severity of the patients' pain was assessed with visual analogue scale (VAS) as daytime and nighttime pain. A 10-cm horizontal line was used for VAS assessment, in which a score of 0 indicated no pain, and 10 indicated the most severe pain. At each evaluation, the average severity of pain that the patient felt in the last 48 hours was questioned. Daytime pain was questioned as the average pain the patient felt while doing routine daily activities, while nighttime pain was questioned as pain that was felt when waking from sleep or shoulder pain that woke the patient from sleep.

Disability and daily functions related to the shoulder were evaluated using the Shoulder Pain and Disability Index (SPADI), which has been previously adapted to Turkish according to validity and reliability study (13). SPADI consists of three subparameters: pain, disability, and total score. High score indicates increased pain and impaired shoulder functions.

\section{Statistical analysis}

Statistical analyses were performed using SPSS 19.0 software (BM Corporation, Armonk, NY). The distribution of the data was determined by Shapiro-Wilk tests. Continuous variables were expressed as mean \pm standard deviation and minimum-maximum, categorical variables as frequency and percent. Categorical variables were compared using Yates' Chi-square test or Fisher's exact test. Groups were compared using independent samples t-tests and Mann-Whitney $U$ tests for parametric and non-parametric variables, respectively. A two-way repeated measures analysis of variance was used to measure the time, group and time-group interaction effect, and a value of $p<0.05$ was accepted as statistically significant.

\section{RESULTS}

A total of 41 patients who met inclusion and exclusion criteria were included in the study. The injection patients group consisted of 19 patients (Group 1), while the non-injection patients group consisted of 22 patients (Group 2). There was no significant difference between the two groups in terms of age, BMI, duration of symptoms, gender, dominant side, and symptomatic side $(p>0.05)$. The demographic and clinical characteristics of the patients are presented in Table 1.

\begin{tabular}{|c|c|c|c|c|c|c|}
\hline & & \multicolumn{2}{|c|}{ Group $1(n=19)$} & \multicolumn{2}{|c|}{ Group $2(n=22)$} & $\mathrm{p}$ \\
\hline \multicolumn{2}{|c|}{ Age (year) } & \multicolumn{2}{|c|}{$\begin{array}{c}44.4 \pm 9.3 \\
(22.0-58.0)\end{array}$} & \multicolumn{2}{|c|}{$\begin{array}{c}50.2 \pm 9.9 \\
(29.0-64.0)\end{array}$} & $0.06^{*}$ \\
\hline \multicolumn{2}{|c|}{$\operatorname{BMI}\left(\mathrm{kg} / \mathrm{m}^{2}\right)$} & \multicolumn{2}{|c|}{$\begin{array}{c}27.8 \pm 3.5 \\
(21.2-34.9)\end{array}$} & \multicolumn{2}{|c|}{$\begin{array}{c}27.2 \pm 3.8 \\
(21.0-33.6)\end{array}$} & $0.660^{*}$ \\
\hline \multirow{2}{*}{\multicolumn{2}{|c|}{ Duration of symptoms (month) }} & \multicolumn{2}{|c|}{$\begin{array}{l}5.2 \pm 2.0 \\
(3.0-9.0)\end{array}$} & \multicolumn{2}{|c|}{$\begin{array}{l}5.8 \pm 2.2 \\
(3.0-9.0)\end{array}$} & $0.362^{*}$ \\
\hline & & $n$ & $\%$ & $\mathrm{n}$ & $\%$ & \\
\hline \multirow{2}{*}{ Gender } & Female & 9 & 47.4 & 13 & 59.1 & \multirow{2}{*}{$0.453 \ddagger$} \\
\hline & Male & 10 & 52.6 & 9 & 40.9 & \\
\hline \multirow{2}{*}{ Dominant side } & Right & 17 & 89.5 & 20 & 90.9 & \multirow{2}{*}{$0.999 \S$} \\
\hline & Left & 2 & 10.5 & 2 & 9.1 & \\
\hline \multirow{2}{*}{ Symptomatic side } & Right & 12 & 63.2 & 15 & 68.2 & \multirow{2}{*}{$0.735 \ddagger$} \\
\hline & Left & 7 & 36.8 & 7 & 31.8 & \\
\hline
\end{tabular}

Note: Data are presented as mean $\pm S D$, minimum-maximum, and number (percent) where applicable. *Independent samples t test, $\neq$ †ates' chi-square test, and \&Fisher's exact test. 
There was no statistically significant difference between the two groups in terms of baseline active and passive ROM (flexion, extension, abduction, adduction, external rotation, internal rotation), pain scores (daytime and nighttime VAS scores), and SPADI (pain, disability, and total) scores ( $p>0.05$ ). Group, time, and group-time were determined to have a statistically significant effect on daytime and nighttime VAS scores $(p<0.05)$. While both groups demonstrated a decrease over time in daytime and nighttime VAS scores, this decrease was significantly greater in Group $1(p<0.05)$. There was a significant change over time in all active and passive ROM measurements $(p<0.05)$. While all ROM measurements of both groups increased over time, this increase was not significantly different between the two groups. There was statistically significant time effect on SPADI pain, disability, and total scores $(p<0.05)$. While all SPADI pain, disability, and total scores decreased over time in both groups, this decrease was similar in both groups (Table 2).

Percentage change was calculated by assessing the difference between the evaluations at baseline and day 21 in both groups. Group 1 demonstrated a statistically greater decrease in pain scores and SPADI pain subscale scores $(p<0.05)$ (Table 3). Adverse effects related to treatment were not observed in any of the patients included in the study.

\section{DISCUSSION}

This study was conducted to evaluate whether or not ultrasound-guided IA glenohumeral injection therapy prior to physical therapy modalities and exercise therapy had an effect on treatment outcomes in patients diagnosed with ACS. According to the findings of this study, it was observed that physical therapy modalities and exercise therapy used in ACS treatment had a positive effect on pain scores, ROM, and disability scores at the end of three weeks. It was determined that ultrasound-guided IA steroid and NSAID injections prior to this treatment increased the positive effect on pain in the short term, but did not provide additional benefit on ROM or disability.

Exercise therapy is of critical importance in ACS treatment (14). It was reported that stretching exercises alone yielded satisfactory results in $90 \%$ of patients diagnosed with ACS (7). Russel et al. (6) reported that group therapy exercises per-

\section{Table 2. Evaluation of the interaction effects of the groups and times on parameters}

\begin{tabular}{|c|c|c|c|c|c|c|c|c|c|c|}
\hline \multirow{2}{*}{ Parameters } & \multicolumn{2}{|c|}{ Day 0} & \multicolumn{2}{|c|}{ Day 21} & \multicolumn{2}{|c|}{ Group } & \multicolumn{2}{|c|}{ Time } & \multicolumn{2}{|c|}{$\begin{array}{l}\text { Group-Time } \\
\text { interaction }\end{array}$} \\
\hline & Group 1 & Group 2 & Group 1 & Group 2 & $f$ & $p$ & $f$ & $p$ & $f$ & $p$ \\
\hline $\begin{array}{c}\text { Range of motion (Active) } \\
\text { Flexion } \\
\text { Extension } \\
\text { Abduction } \\
\text { Adduction } \\
\text { External Rotation } \\
\text { Internal rotation }\end{array}$ & $\begin{array}{c}112.6 \pm 8.7 \\
14.5 \pm 4.7 \\
98.9 \pm 15.6 \\
12.1 \pm 4.5 \\
55.8 \pm 8.5 \\
48.4 \pm 9.6\end{array}$ & $\begin{array}{c}108.2 \pm 12.6 \\
14.8 \pm 4.8 \\
102.3 \pm 19.5 \\
10.7 \pm 5.0 \\
51.4 \pm 13.5 \\
52.3 \pm 13.0\end{array}$ & $\begin{array}{c}133.7 \pm 9.6 \\
21.6 \pm 5.0 \\
122.1 \pm 17.5 \\
15.8 \pm 4.5 \\
65.0 \pm 5.5 \\
60.5 \pm 9.3\end{array}$ & $\begin{array}{c}131.4 \pm 15.5 \\
21.6 \pm 4.2 \\
127.7 \pm 15.4 \\
14.8 \pm 3.6 \\
63.6 \pm 11.9 \\
65.0 \pm 9.5\end{array}$ & $\begin{array}{l}0.462 \\
0.027 \\
0.417 \\
0.348 \\
0.423 \\
0.895\end{array}$ & $\begin{array}{l}0.505 \\
0.871 \\
0.527 \\
0.927 \\
0.524 \\
0.357\end{array}$ & $\begin{array}{c}250.445 \\
42.408 \\
158.333 \\
74.206 \\
66.283 \\
158.099\end{array}$ & $\begin{array}{l}<0.001 \\
<0.001 \\
<0.001 \\
<0.001 \\
<0.001 \\
<0.001\end{array}$ & $\begin{array}{c}2.273 \\
0.321 \\
1.208 \\
0.41 \\
1.833 \\
0.051\end{array}$ & $\begin{array}{l}0.149 \\
0.578 \\
0.286 \\
0.841 \\
0.193 \\
0.823\end{array}$ \\
\hline $\begin{array}{c}\text { Range of motion (Passive) } \\
\text { Flexion } \\
\text { Extension } \\
\text { Abduction } \\
\text { Adduction } \\
\text { External Rotation } \\
\text { Internal rotation }\end{array}$ & $\begin{array}{c}117.1 \pm 9.0 \\
16.3 \pm 5.7 \\
105.3 \pm 17.1 \\
13.4 \pm 7.1 \\
57.1 \pm 9.3 \\
51.1 \pm 8.9\end{array}$ & $\begin{array}{c}111.6 \pm 12.2 \\
15.9 \pm 6.1 \\
109.1 \pm 20.7 \\
12.5 \pm 6.1 \\
52.7 \pm 12.2 \\
54.5 \pm 10.9\end{array}$ & $\begin{array}{c}139.7 \pm 8.6 \\
27.4 \pm 8.4 \\
132.1 \pm 18.4 \\
17.6 \pm 7.5 \\
68.9 \pm 7.6 \\
63.4 \pm 9.0\end{array}$ & $\begin{array}{c}138.6 \pm 15.2 \\
26.6 \pm 7.6 \\
137.7 \pm 19.0 \\
18.0 \pm 7.2 \\
65.9 \pm 10.6 \\
67.3 \pm 8.4\end{array}$ & $\begin{array}{l}1.089 \\
0.232 \\
0.432 \\
0.213 \\
1.079 \\
0.946\end{array}$ & $\begin{array}{l}0.310 \\
0.636 \\
0.519 \\
0.650 \\
0.313 \\
0.344\end{array}$ & $\begin{array}{l}398.375 \\
222.893 \\
239.671 \\
70.223 \\
75.000 \\
122.143\end{array}$ & $\begin{array}{l}<0.001 \\
<0.001 \\
<0.001 \\
<0.001 \\
<0.001 \\
<0.001\end{array}$ & $\begin{array}{c}1.506 \\
0.568 \\
0.630 \\
0.415 \\
0.238 \\
0.12\end{array}$ & $\begin{array}{l}0.236 \\
0.461 \\
0.438 \\
0.527 \\
0.632 \\
0.915\end{array}$ \\
\hline $\begin{array}{l}\text { VAS daytime } \\
\text { VAS nighttime }\end{array}$ & $\begin{array}{l}6.1 \pm 1.4 \\
7.3 \pm 2.2\end{array}$ & $\begin{array}{l}7.0 \pm 2.0 \\
7.5 \pm 2.0\end{array}$ & $\begin{array}{l}2.0 \pm 0.7 \\
2.0 \pm 0.6\end{array}$ & $\begin{array}{l}4.3 \pm 0.8 \\
4.1 \pm 1.0\end{array}$ & $\begin{array}{l}13.295 \\
8.636\end{array}$ & $\begin{array}{l}0.002 \\
0.009\end{array}$ & $\begin{array}{l}248.124 \\
192.400\end{array}$ & $\begin{array}{l}<0.001 \\
<0.001\end{array}$ & $\begin{array}{l}7.410 \\
12.860\end{array}$ & $\begin{array}{l}0.014 \\
0.002\end{array}$ \\
\hline $\begin{array}{l}\text { Pain score } \\
\text { Disability score } \\
\text { Total score }\end{array}$ & $\begin{array}{l}77.0 \pm 14.3 \\
58.1 \pm 14.1 \\
65.1 \pm 11.9\end{array}$ & $\begin{array}{l}80.3 \pm 16.0 \\
68.4 \pm 24.0 \\
72.9 \pm 19.0\end{array}$ & $\begin{array}{c}39.8 \pm 7.8 \\
43.9 \pm 10.4 \\
42.3 \pm 7.4\end{array}$ & $\begin{array}{c}47.0 \pm 9.3 \\
46.4 \pm 12.2 \\
46.7 \pm 8.2\end{array}$ & $\begin{array}{l}1.112 \\
0.744 \\
1.445\end{array}$ & $\begin{array}{l}0.306 \\
0.400 \\
0.245\end{array}$ & $\begin{array}{l}336.726 \\
72.946 \\
238.665\end{array}$ & $\begin{array}{l}<0.001 \\
<0.001 \\
<0.001\end{array}$ & $\begin{array}{l}1.800 \\
1.726 \\
0.290\end{array}$ & $\begin{array}{l}0.196 \\
0.205 \\
0.597\end{array}$ \\
\hline
\end{tabular}

Note: Data are presented as mean \pm SD. p: Two way repeated measures for ANOVA, p value of $<0.05$ is considered statistically significant, F: Test statistics (analysis of variance with repeated measurements).

VAS: Visual analogue scale, SPDI: Shoulder Pain and Disability Index. 
Table 3. Percentage changes of the parameters between baseline and day 21

\begin{tabular}{|c|c|c|c|}
\hline Parameters & Group 1 & Group 2 & $p$ \\
\hline $\begin{array}{c}\text { Range of motion (Active) } \\
\text { Flexion } \\
\text { Extension } \\
\text { Abduction } \\
\text { Adduction } \\
\text { External Rotation } \\
\text { Internal rotation }\end{array}$ & $\begin{array}{c}18.9 \pm 6.4 \\
63.2 \pm 63.4 \\
24.1 \pm 11.6 \\
42.1 \pm 50.7 \\
18.8 \pm 17.8 \\
27.0 \pm 15.7\end{array}$ & $\begin{array}{c}21.8 \pm 9.8 \\
59.1 \pm 51.9 \\
26.9 \pm 14.6 \\
59.1 \pm 58.4 \\
28.6 \pm 23.8 \\
28.5 \pm 20.6\end{array}$ & $\begin{array}{l}0.436^{+} \\
0.823^{*} \\
0.508^{*} \\
0.330^{*} \\
0.148^{*} \\
0.792^{*}\end{array}$ \\
\hline $\begin{array}{c}\text { Range of motion (Passive) } \\
\text { Flexion } \\
\text { Extension } \\
\text { Abduction } \\
\text { Adduction } \\
\text { External Rotation } \\
\text { Internal rotation }\end{array}$ & $\begin{array}{c}19.6 \pm 6.3 \\
75.0 \pm 47.6 \\
26.3 \pm 10.8 \\
43.9 \pm 49.1 \\
23.2 \pm 20.1 \\
25.8 \pm 16.4\end{array}$ & $\begin{array}{l}24.7 \pm 11.4 \\
78.4 \pm 48.9 \\
28.1 \pm 15.6 \\
62.1 \pm 56.9 \\
29.0 \pm 23.8 \\
26.0 \pm 17.4\end{array}$ & $\begin{array}{l}0.089^{*} \\
0.823^{*} \\
0.673^{*} \\
0.282^{*} \\
0.414^{*} \\
0.973^{*}\end{array}$ \\
\hline $\begin{array}{l}\text { VAS daytime } \\
\text { VAS nighttime }\end{array}$ & $\begin{array}{l}67.4 \pm 9.9 \\
70.3 \pm 9.7\end{array}$ & $\begin{array}{l}33.4 \pm 18.0 \\
43.3 \pm 12.6\end{array}$ & $\begin{array}{l}<0.001^{+} \\
<0.001^{*}\end{array}$ \\
\hline $\begin{array}{l}\text { Pain score } \\
\text { Disability score } \\
\text { Total score }\end{array}$ & $\begin{array}{c}47.9 \pm 6.0 \\
23.2 \pm 11.1 \\
34.5 \pm 6.9\end{array}$ & $\begin{array}{c}40.5 \pm 9.9 \\
28.0 \pm 16.2 \\
33.8 \pm 10.7\end{array}$ & $\begin{array}{l}0.007^{*} \\
0.255^{+} \\
0.819^{*}\end{array}$ \\
\hline
\end{tabular}

Note: Data are presented as mean \pm SD. p value of $<0.05$ is considered statistically significant; "Independent samples $t$ test, ${ }^{+}$Mann Whitney $U$ test. VAS: Visual analogue scale, SPDI: Shoulder Pain and Disability Index.

formed at the hospital under physiotherapist supervision was more effective and allowed more rapid improvement than individual physiotherapy or a home exercise program. Other treatment methods are usually combined with exercise therapy. The use of physical therapy modalities such as superficial and deep heat therapy and analgesic currents can effect pain and the extensibility of soft tissues, and may increase the effectiveness of exercise therapy $(4,5)$. Leung et al. (4) reported that the addition of deep heat to stretching exercises provided more improvement in pain and function compared to the addition of superficial heat or stretching exercises alone. In the same study, patients with deep heat therapy added to stretching exercises showed greater increase in ROM compared to patients with superficial heat therapy added to stretching exercises. In another study (15), it was reported that the addition of TENS therapy to exercise therapy provided more pain relief and greater ROM increase in patients diagnosed with ACS.

Arslan et al. (16) reported that IA steroid treatment was as effective as physical therapy modalities consisting of hot pack and TUS, combined with exercise and oral NSAID therapy. In contrast, Calis et al. (8) used physical therapy modalities comprised of hot pack, TUS, and TENS, together with exercise therapy. It was reported that the 10-day treatment program consisting of physical therapy modalities and exercise therapy had a greater positive effect on pain, ROM, and function in the short term, compared to steroid injection alone or exercise therapy alone. In another study (17), it was reported that steroid injection therapy provided a greater decrease in pain and disability compared to the physiotherapy program. Ryans et al. (18) reported that IA steroid injection reduced shoulder disability in the short term, while physiotherapy was more effective in increasing ROM. According to the results of previous studies, the information regarding the superiority of IA injection therapy over other therapy modalities is unclear. In the present study, since steroid injections were combined with other treatment methods, we are unable to provide any data regarding the effects of steroid injections alone, however, these results indicate that the combination of physical therapy modalities and exercise therapy has a positive effect on pain, ROM, and disability in patients with ACS.

The use of IA injection therapy together with other conservative treatment methods aims to increase the efficacy of treatment in ACS. Bulgen et al. (19) found that the addition of IA steroid injections to a home exercise program yielded early pain reduction and ROM increase compared to interventions such as mobilization exercises and ice therapy. However, Carette et al. (11) reported that adding supervised 
physiotherapy to patients undergoing IA steroid and exercise therapy provided a more rapid improvement in ROM at the end of 6 weeks. In the present study, it was determined that IA injection therapy combined with other treatment methods had a significant effect on pain reduction in the short term. It may be assumed that ACS patients with less shoulder pain may exercise more aggressively, thus achieving a greater increase in ROM. However in this study, it was observed that both groups had similar ROM increase. Nevertheless, in the aforementioned study (11), supervised physiotherapy was not applied in the same manner in all patients; while acute patients were applied TENS, ice, and exercise, chronic patients were applied TUS, ice, and exercise therapy. As for this present study, all patients consisted of chronic phase ACS patients, and all patients received the same physical therapy modalities and exercise therapy. In the other study, the fact that the patients consisted of both acute and chronic ACS patients and that different physical therapy modalities were applied to the patients may have disrupted the homogeneity of the study and affected the results.

Different injection contents have been used in IA glenohumeral injections applied in the treatment of ACS. Yoon et al. (20) reported that both $40 \mathrm{mg}$ and $20 \mathrm{mg}$ dosage of IA triamcinolone acetonide were effective in the improvement of disability, pain, and ROM in ACS, but they did not observe a significant difference between the effects of the two steroid doses. In another study (21), it was reported that $40 \mathrm{mg}$ IA triamcinolone was more effective than $10 \mathrm{mg}$ triamcinolone and the response was dose-dependent. Rizk et al. (22) reported that the IA administration of a combination of methylprednisolone and lidocaine was more effective in reducing pain than lidocaine injection alone. In the present study, patients were administered intraarticular injections of a combination of betamethasone and lidocaine. This is because betamethasone has a longer effect than other steroid preparations, and we mostly use combination of betamethasone and lidocaine in our routine practice.

\section{Limitations of the study}

The main limitation of this study was that short-term outcomes were evaluated after the injection. Therefore, there is no data in this study regarding the additional benefits of IA injection on the physical therapy and rehabilitation program in the long term. Despite both groups having similar baseline parameters, another major limitation was that study groups were formed according to whether or not patients consented to being administered injections. Yet another limitation was this study's retrospective design. Furthermore, only one instrument of measure was used to evaluate disability of patients. Other measurement instruments may have yielded different results.

\section{CONCLUSION}

The results of the current study demonstrated that IA steroid and NSAID injections added to physical therapy modalities and exercise therapy increased the effect of pain relief in the short term but did not contribute to improving ROM and disability in patients diagnosed with ACS. Intraarticular injection therapy together with exercise and physical therapy may be beneficial in ACS patients with predominant symptoms of pain. Randomized studies using different steroid preparations and different dosages in larger patient groups are needed to better understand the effects of IA injection added to physical therapy modalities and exercise therapy.

\section{ACKNOWLEDGEMENT}

Peer-Review

Externally Peer Reviewed

Conflict of Interest

The authors declare that they have no conflict of interests regarding content of this article.

Financial Support

The authors report no financial support regarding content of this article.

Ethical Declaration

Ethical approval was obtained from the Çanakkale Onsekiz Mart University, Medical Faculty Clinical / Human Research Ethics Committee with date 07.05.2020 and number 2020-07 and Helsinki Declaration rules were followed to conduct this study.

\section{Support Resources}

No financial support was used by authors during this study.

\section{REFERENCES}

1. Robinson $C$, Seah KM, Chee $Y$, Hindle P, Murray I. Frozen shoulder. J Bone Joint Surg Br. 2012;94: 1-9. https://doi. org/10.1302/0301-620X.94B1.27093

2. Tighe $\mathrm{CB}$, Oakley JW. The prevalence of a diabetic condition and adhesive capsulitis of the shoulder. South Med J. 2008;101: 591-5. https://doi.org/10.1097/SMJ.0b013e3181705d39

3. Levine WN, Kashyap CP, Bak SF, Ahmad CS, Blaine TA, Bigliani LU. Nonoperative management of idiopathic adhesive capsulitis. J Shoulder Elbow Surg. 2007;16: 569-73. https:// doi.org/10.1016/j.jse.2006.12.007

4. Leung MS, Cheing GL. Effects of deep and superficial heating in the management of frozen shoulder. J Rehabil Med. 2008;40: 145-50. https://doi.org/10.2340/16501977-0146

5. Kelley MJ, Shaffer MA, Kuhn JE, et al. Shoulder pain and mobility deficits: adhesive capsulitis. J Orthop Sports Phys Ther 2013;43: A1-A31. https://doi.org/10.2519/jospt.2013.0302 
6. Russell S, Jariwala A, Conlon R, Selfe J, Richards J, Walton M. A blinded, randomized, controlled trial assessing conservative management strategies for frozen shoulder. J Shoulder Elbow Surg. 2014;23: 500-7. https://doi.org/10.1016/j. jse.2013.12.026

7. Griggs SM, Ahn A, Green A. Idiopathic adhesive capsulitis: a prospective functional outcome study of nonoperative treatment. J Bone Joint Surg Am. 2000;82: 1398.

8. Calis M, Demir H, Ulker S, Kirnap M, Duygulu F, Calis HT. Is intraarticular sodium hyaluronate injection an alternative treatment in patients with adhesive capsulitis? Rheumatol Int. 2006;26: 536-40. https://doi.org/10.1007/s00296-005-0022-2

9. Raeissadat SA, Rayegani SM, Langroudi TF, Khoiniha M. Comparing the accuracy and efficacy of ultrasound-guided versus blind injections of steroid in the glenohumeral joint in patients with shoulder adhesive capsulitis. Clin Rheumatol. 2017;36: 933-40. https://doi.org/10.1007/s10067-016-3393-8

10. Lorbach O, Kieb M, Scherf C, Seil R, Kohn D, Pape D. Good results after fluoroscopic-guided intra-articular injections in the treatment of adhesive capsulitis of the shoulder. Knee Surg Sports Traumatol Arthrosc. 2010;18: 1435-41. https://doi. org/10.1007/s00167-009-1030-7

11. Carette S, Moffet H, Tardif J, et al. Intraarticular corticosteroids, supervised physiotherapy, or a combination of the two in the treatment of adhesive capsulitis of the shoulder: A placebocontrolled trial. Arthritis Rheum. 2003;48: 829-38. https://doi. org/10.1002/art.10954

12. White DJ: The shoulder. In: Norkin CC, White DJ (eds), Measurement of joint motion: a guide to goniometry. Philadelphia: F. A. Davis Company; 2016; 66-115.

13. Bumin G, Tüzün EH, Tonga E. The Shoulder Pain and Disability Index (SPADI): Cross-cultural adaptation, reliability, and validity of the Turkish version. J Back Musculoskelet Rehabil. 2008;21: 57-62.
14. Bal A, Eksioglu E, Gulec B, Aydog E, Gurcay E, Cakci A. Effectiveness of corticosteroid injection in adhesive capsulitis. Clin Rehabil. 2008;22: 503-12. DOI: https://doi. org/10.1177/0269215508086179

15. Rizk T, Christopher R, Pinals R, Higgins A, Frix R. Adhesive capsulitis (frozen shoulder): a new approach to its management. Arch Phys Med Rehabil. 1983;64: 29-33.

16. Arslan S, Çeliker R. Comparison of the efficacy of local corticosteroid injection and physical therapy for the treatment of adhesive capsulitis. Rheumatol Int. 2001;21: 20-3. https:// doi.org/10.1007/s002960100127

17. van der Windt D, Koes BW, Deville W, Boeke AJ, de Jong BA, Bouter LM. Effectiveness of corticosteroid injections versus physiotherapy for treatment of painful stiff shoulder in primary care: randomised trial. BMJ. 1998;317: 1292-6. https://doi.org/10.1136/bmj.317.7168.1292

18. Ryans I, Montgomery A, Galway R, Kernohan W, McKane R. A randomized controlled trial of intra-articular triamcinolone and/or physiotherapy in shoulder capsulitis. Rheumatology. 2005;44: 529-35. https://doi.org/10.1093/rheumatology/ keh535

19. Bulgen D, Binder A, Hazleman B, Dutton J, Roberts S. Frozen shoulder: prospective clinical study with an evaluation of three treatment regimens. Ann Rheum Dis. 1984;43: 353-60. https://doi.org/10.1136/ard.43.3.353

20. Yoon S-H, Lee HY, Lee HJ, Kwack K-S. Optimal dose of intraarticular corticosteroids for adhesive capsulitis: a randomized, triple-blind, placebo-controlled trial. Am J Sports Med. 2013;41: 1133-9. https://doi.org/10.1177/0363546513480475

21. De Jong BA, Dahmen R, Hogeweg JA, Marti RK. Intraarticular triamcinolone acetonide injection in patients with capsulitis of the shoulder: a comparative study of two dose regimens. Clin Rehabil. 1998;12: 211-5. https://doi. org/10.1191/026921598673772420

22. Rizk TE, Pinals RS, Talaiver AS. Corticosteroid injections in adhesive capsulitis: investigation of their value and site. Arch Phys Med Rehabil. 1991;72: 20-2. 